\title{
Exploring Self-Efficacy and Anxiety in First-Year Nursing Students Enrolled in a Discipline-Specific Scholarly Writing Course
}

Kim M. Mitchell

Red River College, kmmitchell@rrc.ca

Tom Harrigan

Red River College, tharrigan@rrc.ca

Torrie Stefansson

Red River College, tjanelles90@gmail.com

Holly Setlack

Red River College, hollyp.setlack@hotmail.com

Follow this and additional works at: https://qane-afi.casn.ca/journal

Part of the Curriculum and Instruction Commons, Educational Assessment, Evaluation, and Research Commons, Educational Psychology Commons, and the Other Nursing Commons

\section{Recommended Citation}

Mitchell, Kim M.; Harrigan, Tom; Stefansson, Torrie; and Setlack, Holly (2017) "Exploring Self-Efficacy and Anxiety in First-Year Nursing Students Enrolled in a Discipline-Specific Scholarly Writing Course," Quality Advancement in Nursing Education - Avancées en formation infirmière: Vol. 3: Iss. 1, Article 4.

DOI: https://doi.org/10.17483/2368-6669.1084

This Article is brought to you for free and open access by Quality Advancement in Nursing Education - Avancées en formation infirmière. It has been accepted for inclusion in Quality Advancement in Nursing Education - Avancées en formation infirmière by an authorized editor of Quality Advancement in Nursing Education - Avancées en formation infirmière. 


\section{Exploring Self-Efficacy and Anxiety in First-Year Nursing Students Enrolled in a Discipline-Specific Scholarly Writing Course}

\section{Cover Page Footnote}

The authors would like to thank Mr. Ashley Blackman, Director of Research and Planning at Red River College for his advice and support during the planning and implementation of this project. Note de la page couverture Les auteurs tiennent à remercier $\mathrm{M}$. Ashley Blackman, directeur de la recherche et de la planification au Red River College pour ses conseils et son soutien lors de la planification et de la mise en œuvre de ce projet. 
Discipline-specific writing is the preferable approach for teaching nursing students the skills to participate fully in academic discussions (Luthy, Peterson, Lassetter, \& Callister, 2009). For students to successfully communicate in the manner associated with their discipline, they must learn to write fluently in that discipline (Van de Poel \& Gasiorek, 2012); however, many students enter nursing programs unaware of the academic rigour required to be successful (Sprenger, 2013). Including academic writing as a program requirement is a difficult sell to students who believe nursing is a practical profession and, thus, may believe there is no place for writing in nursing (Whitehead, 2002).

Writing scholars have refuted the myth that all academics have a natural ability and drive to write, as both novice and experienced writers struggle with writing (Antoniou \& Moriarty, 2008). Students best grasp the structure and intellectuality of academic writing by reading lots and writing lots (McVey, 2008), preferably from sources specific to their disciplines. As novice writers, students have expressed frustration with the impersonal nature of academic style, which limits their perceived creativity, ability to insert their personal flair into the process, and causes them to question the ownership of their ideas and work. This sense of depersonalization negatively affects perceived writing self-efficacy and, thus, justifies the academic writing process as a worthy element of study (Gimenez, 2012; Pittam, Elander, Lusher, Fox, \& Payne, 2009; Whitehead, 2002).

Students often mistakenly see their writing skills as fixed (Walsh, Prokos, \& Bird, 2014). They fail to recognize that knowledge of writing from one discipline may not successfully transfer to a new discipline until knowledge of that discipline's preferences for writing conventions is mastered. Discipline-specific methods of writing instruction have been found to be more successful than generic methods (Carstens, 2011; Gimenez, 2012), but little is known about whether writing instruction can influence student writing self-efficacy and anxiety. The purpose of the present investigation was to identify if changes to writing self-efficacy and writing anxiety will occur in first-year baccalaureate nursing students who are exposed to a discipline-specific scholarly writing course employing scaffolding strategies as the primary instructional method. Concurrently, this study was the pilot test for a new measure assessing writing self-efficacy, the Self-Efficacy Scale for Academic Writing.

\section{Theoretical Background}

This study and the discipline-specific course structure under investigation were built on the principles of Bandura's self-efficacy theory and employed scaffolding as the instructional method.

\section{Bandura's Self-Efficacy Theory}

Bandura's (1997) self-efficacy theory defines self-efficacy as "beliefs in one's capabilities to organize and execute the courses of action required to produce given attainments" (p. 3). Bandura identifies the sources of information influencing self-efficacy as mastery of a task, emotional arousal, social persuasion in the form of feedback from significant others, and vicarious experiences defined as self-comparisons with others similar to the observer. Context, anxiety level, understanding the task, previous writing experience, verbal feedback, and confidence all influence writing self-efficacy. These factors have the potential to interact with each other and influence students' performance, effort, perseverance with writing tasks, and the accompanying emotional responses that may result (Pajares, 2003; Prat-Sala \& Redford, 2012). 


\section{Scaffolding in Writing Instruction}

Scaffolding instructional methods in writing courses are built around two processes: appropriate leveling of writing material for the learners, which includes completing portions of the work in progressive stages, and collaborative support from instructors (Benko, 2012; Gazza \& Hunker, 2012; Vanderburg, 2006; Walsh et al., 2014). The instructor, tutor, or more advanced peer acts as the scaffold in the process. The instructor as scaffold slowly withdraws support while building capacity in the learner to complete the task independently. Models of scaffolding are sometimes represented as a building structure with a foundation, framing, and braces, such as the one presented by Gazza and Hunker. Benko created a scaffolding model by merging two scaffolding theories created by Langer and Applebee and Wood et al. (as cited in Benko). The model is a process which starts with task selection, oscillates between the recursive elements of teacher instruction and teacher stance, and, finally, results in a process of "letting go" where the student internalizes learning and can independently complete the task. A presentation of this model of scaffolding, including relevant definitions, appears in the Appendix to this paper. The structure and leveling of writing assignments in the course scholarly writing, which was the discipline-specific writing intervention under investigation in this study, are also described.

Instructor involvement in writing instruction is the critical element in the success of a scaffolding method. Instructors' responsibilities, beyond basic instruction, include modeling successful writing, helping writers find their inner voice, and guiding writers to integrate aspects of their disciplinary discourse into their writing (Vanderburg, 2006). A collaborative rather than an authoritarian stance is crucial in this process. Collaborative instruction necessitates that instructors speak with students about their work as if they were capable writers and readers rather than prescribe the writing process (Benko, 2012; Vanderburg, 2006). Opportunities for these formative discussions of writing, without the threat of loss of grades, have high value in the process prior to the summative feedback given in the formal grading process (Benko, 2012; Walsh et al., 2014). Instructor stance facilitates the "buy-in" from students to the writing assignments and process (Walsh et al.). Breaking the task into discrete portions prevents cognitive overload in students keeping them from feeling overwhelmed by the complexity of an academic paper (Walsh et al.). Allowing students their choice of topic and control over how they approach that topic gives students authority over their writing, which culminates in the internalization process and greater student independence as an academic writer (Benko, 2012). The degree to which a sense of independence is achieved could influence writing self-efficacy.

\section{Review of the Literature}

Writing self-efficacy (WSE) in post-secondary students has been examined in multidisciplinary samples including basic writing students (Goodman \& Cirka, 2009; Jones, 2008; Martinez, Knock, \& Cass, 2011; MacArthur, Philippakos, \& Graham, 2016), writing centre or writing course students (Williams \& Takaku, 2011; Zimmerman \& Bandura, 1994), and college English students in foreign countries (Van de Poel \& Gasiorek, 2012; Woodrow, 2011), as well as in specific disciplines such as psychology (Prat-Sala \& Redford, 2012; Sanders-Reio, Alexander, Reio, \& Newman, 2014), education (Ekholm, Zumbrunn, \& Conklin, 2015; Pajares \& Johnson, 1994), and social work (Woody et al., 2014). Nursing-specific studies examining WSE include one doctoral dissertation using a mixed method concurrent triangulation design (Sprenger, 2013) and one quasi-experimental design with a study and comparison group examining WSE in nurse-to-degree students (Miller, Russell, Cheng, \& Skarbek, 2015). Only a very small number of these studies employ a pretest-post-test method to assess change over time 
in WSE (Goodman \& Cirka, 2009; Jones, 2008; McArthur et al., 2016; Miller et al., 2015; Van de Poel \& Gasiorek, 2012; Woody et al., 2014) and these authors all identified that WSE significantly improves when self-efficacy is consciously considered as a part of instructional methods. Each of these studies employed different instructional environments including discipline-specific courses (Van de Poel \& Gasiorek, 2012; Woody et al.), a writing fellow's program with an emphasis on writing tutoring (Goodman \& Cirka, 2009), and various scaffolding strategies which provide step-by-step writing activities leading to the completion of a final paper (McArthur et al., 2016; Miller et al., 2015). The influence writing instruction has on WSE likely has less to do with the specific tasks students are asked to perform when learning to write and more to do with how instructors influence the process (Woodrow, 2011).

\section{Writing Self-Efficacy and Performance}

Goodman and Cirka (2009) and Pajares (2003) summarize the claims associated with how high WSE influences performance in terms of student interest in the task, greater effort, higher resiliency, and more effective problem-solving strategies. In contrast, low self-efficacy students are more likely to have self-doubt, give up in the face of difficulty, be grade oriented rather than view the task's value in terms of knowledge gains, and choose less challenging topics. Jones (2008) identified that the WSE scores of weaker students had a greater effect on course grade than those of stronger students.

Finding a reliable method to assess performance has been problematic in studies with variation in the definitions of "performance", likely contributing to the conflicting results. Performance has been assessed using on-demand or in-class writing exercises (MacArthur et al., 2016; Pajares \& Johnson, 1994; Woody et al., 2014), or, more rarely, complete papers (Miller et al., 2015), and most of these writing assessments double as course assignments. Pajares and Johnston (p. 319) acknowledge the "salient limitation" present in using performance as a research variable to assess writing due to the lack of objectivity during assessment. Any number of biases and diverse interpretations are present in the assessment of written work, which complicates the ability of these assessments to be consistently scored. For example, Woody et al. (2014) reported difficulties with rating inconsistencies of their paragraph writing assessment. When the course instructors acted as raters, a statistically significant improvement in writing was observed from before and after the writing course. The statistical significance disappeared when blind raters were used. Miller et al. (2015) found performance improved between the first and second essay assessments while remaining stable between the second and third. Specific areas of improvement included organization, word choice, sentence fluency, conventions, and presentation. Voice/stance and ideas did not improve across essays. Very few studies assess change in writing performance, which would involve using specific rubric scores as part of their methodology, with two exceptions being Miller et al. (2015) and Woody et al. (2014) Most often, performance is analyzed using letter grades (Goodman \& Cirka, 2009; Williams \& Takaku, 2011), and correlation and/or regression statistics are applied. The ability of WSE to predict grades using regression statistics has been variable and small, and ranges from no predictive ability in basic writing students (MacArthur et al., 2016) to predicting 5.4\% variance in grades in first-year psychology groups, increasing to $10 \%$ in second-year students (Prat-Sala \& Redford, 2012). 


\section{WSE and Anxiety}

In examining the influence of emotional arousal as one of Bandura's identified sources of self-efficacy, anxiety (Martinez et al., 2011; Woodrow, 2011) and writing apprehension (Goodman \& Cirka, 2009; Pajares \& Johnson, 1994; Sanders-Reio et al., 2014) are the most frequently assessed in writing contexts. These authors all identified negative correlations between anxiety or apprehension and WSE. Two of these studies examined apprehension from before and after intervention, and the results were conflicting. Goodman and Cirka observed a statistically significant improvement in apprehension while Pajares and Johnson found apprehension remained resilient. Woodrow (2011) states that WSE has a direct influence on writing performance, and anxiety influences performance through its effects on WSE rather than through a direct relationship with performance. WSE affects performance via its positive influence on the behaviours typical of strong students, for example, seeking help with their writing (Jones, 2008; Walker, 2003; Woodrow, 2011).

\section{WSE Comparisons Between Student Subgroups}

Few studies have explored differences in WSE in various subgroups of students including self-reported writing experience, help-seeking patterns, and self-regulatory ability to stay on pace with writing instruction where writing activities are taught in a scaffolded manner and completed in small stages across a course. If student populations with lower WSE cluster into any of these subgroups, students with these characteristics may be potential targets for population-specific interventions. Martinez et al. (2011) examined the role of leisure writing in their path analysis model of WSE. Leisure writing may be considered a component of writing experience as it is defined as an act of writing voluntarily for pleasure. Martinez et al. concluded that leisure writing had a small positive influence on WSE. Sprenger (2013) tested if there was a difference in WSE between nursing students who had taken a previous college writing course and students who had not, and found no significant difference. Williams and Takaku (2011) examined help seeking by exploring the behaviours of both ESL and non-ESL writing centre students. These authors identified that the relationship between WSE and writing performance is mediated by seeking help at a writing centre. In comparing WSE in ESL and non-ESL students, the same authors identified that ESL students were more likely to seek writing centre help, and when they did seek help, they often outperformed the domestic students in terms of final grades on writing assignments. These authors concluded that help seeking had the greatest influence on student grades, rather than WSE level. Assessments of self-regulation have been merged with WSE in several measurement tools (Jones, 2008; MacArthur et al., 2016; Zimmerman \& Bandura, 1994); however, there is some evidence via factor analysis that self-regulation functions as a separate construct (Jones, 2008). How WSE is related to student self-regulatory behaviours, in terms of how it motivates students to stay on pace with scaffolded writing activities contributing to a final academic paper, has not been established.

\section{Writing Self-Efficacy in Nursing}

Thus far, no published studies have included generic nursing students at the beginning of their program in terms of their WSE experiences; however, two systematic reviews have been published examining the literature that describes writing instruction in nursing programs (Oermann et al., 2014; Troxler, Vann, \& Oermann, 2011). The authors of these reviews agree that the majority of literature discussing writing approaches in nursing are anecdotal and refer to specific local circumstances in the absence of empirical testing. Troxler et al. (2011) examined 
nine articles discussing writing instruction in baccalaureate nursing programs using both standalone and curriculum-wide approaches and concluded that research examining student writing outcomes is limited.

The single WSE study published in nursing (Miller et al., 2015) focused on the writing experiences of nurse-to-degree students near the end of their program. These students were exposed to a writing-intensive intervention delivered jointly by nursing and writing program faculty. Writing instruction involved scaffolding various assignments of increasing complexity throughout the course and identified a statistically significant improvement in self-efficacy and some improvement in writing performance, as reported above.

Mandleco, Bohn, Callister, Lassetter, and Carlton (2012), although they did not measure WSE, published one of the few writing-intervention studies in a nursing undergraduate population. Their intervention was a goals-based instructional method that focused on punctuation, grammar, voice, plagiarism, clarity of writing, and paragraph and sentence structure. Examples were provided, and activities and assignments allowed students to practice the strategies demonstrated in class. Their measurement of writing improvement was a 26category CLIPS questionnaire that focused primarily on surface errors in writing. Students improved significantly in 12 categories in the areas of punctuation, word usage, and sentence structure. Confidence ratings were also requested from students and the authors identified that student confidence was consistently higher during informal assignments, where perfect grammar, lack of grading, and shorter length reduced the pressure students felt while writing, when compared to the high-stake context of formal writing assignments. The authors were only anecdotally able to report that student writing improved in their sample as only the grammatical questionnaire was used to assess performance.

In light of the gaps and variable findings in the WSE literature and the paucity of writing research in the nursing discipline specifically, the following research questions were addressed in this analysis:

1. Do WSE and anxiety improve from early to post discipline-specific writing course through implementation of a scaffolding method of instruction?

2. Does WSE predict the grade students achieve on their scholarly paper assignment?

3. How do WSE and anxiety differ between participants based on past writing history, help-seeking (contact with a course instructor or using a family member or a friend as an editor), and self-regulatory behaviours (ability to stay on task with the weekly writing activities which contributed to their final paper)?

\section{Method}

\section{Participants}

Participants in this study either directly enrolled in the nursing program (minimum entry requirement: $60 \%$ average in prerequisite courses) or entered through a college preparation program designed to help mature students update their educational prerequisites. The wait to be admitted to this accelerated three-year program averages two years. The scholarly writing course is a required course for all first-year nursing students. All 173 students registered in two sections of the course, scholarly writing, in the second term of the first year of their baccalaureate nursing program were eligible to participate. Of the 173 students, 135 (78.0\%) returned completed 
questionnaires at T1, and $72(41.6 \%)$ at T2. From these responses, 64 were matched for the full analysis (37\% response rate).

At T2, students were asked to provide their paper grade by self-declaring their letter grade received. This process was chosen due to a desire to keep the data collection process anonymous. In comparing the self-reported paper grade in the sample to the letter grades achieved by the entire class, letter grades were higher in the sample (sample proportion reporting a grade of B or higher: $80.5 \%$ ) than actual paper grades achieved by the class (class proportion receiving a grade of $\mathrm{B}$ or higher: $68.8 \%$ ).

\section{Procedure and Design}

The study employed a one-group quasi-experimental pretest/post-test design. Ethical approval was obtained from the research ethics board at the college of instruction located in a prairie province in Canada. Informed consent was secured by presenting all participants with a letter attached to the front of a questionnaire package following an in-class presentation from the first author. Because the first author was the course leader, an instructor not involved in the research study was assigned to collect and store the questionnaires in a locked filing cabinet with assurance to the participants that their responses would not be viewed until final grades for the course were submitted to student records. In order to keep participants' responses anonymous, participants were asked to create their own identification code using their mother's initials and birth date, which was later used to match the early and post-course questionnaires.

The first questionnaire (T1) was distributed on the fourth class into the term after topics such as voice, plagiarism, citation, and website evaluation had been completed and their paper assignment had been explained (January 2012). The participants' first writing exercise for the course, which asked them to describe their history with writing, was requested as data in the study. Critical analyses of these written texts are not discussed in this article but are referred to in corroboration of findings in the discussion section of this paper. The final questionnaire (T2) was distributed after course completion, following the release of paper grades and final course grades, and took place in the third term of the program (March 2012).

\section{Course Description}

This scholarly writing course is one of six discipline-specific writing courses associated with baccalaureate nursing programs across Canada (Andre \& Graves, 2013). Course dynamics involve instruction of students from multiple regional, international, and cultural backgrounds. The challenge was to deliver meaningful writing instruction to a large group of students in a lecture theatre and blend both classroom and online delivery. The scaffolding of assignments and scholarly paper tasks was the principle writing instructional method. Details of the course topics, assignments, weekly paper completion tasks, instructor responsibilities, rationale for inclusion of topic and how the course applies the principles of scaffolding as a process (Benko, 2012), and self-efficacy theory (Bandura, 1997) are presented in the appendix.

The course required students to produce a final academic paper worth $60 \%$ of their final grade. Students wrote the scholarly paper in stages throughout the term. The instructor provided three to five topic choices, which change from year-to-year, and are either focused on a nursing issue or nursing practice, or of interest to nursing by nature of a connection to psychological or physical health. For example, the students in this sample chose from topics such as suicide, 
victim blaming, empathy, student cheating, and bullying. Students' final papers synthesized their chosen research sources into a three-page paper incorporating two to three main headings.

Students were also required to submit an outline of their topic, upload the notes they took while preparing to write their paper, and submit one example of an early draft of their work. Feedback was provided on these early draft preparation items at student request as class size precluded giving extensive feedback to all students. This process meant that the students were given only soft due dates for submitting these items. Many students sought feedback on one or more of these preparation items as it was strongly encouraged, but there were other students who chose to upload these components at the same time they submitted their final paper for grading, making it possible that some students did not stay on pace with the course and completed all the paper writing tasks within days or hours of the due date.

\section{Measures}

Self-Efficacy Scale for Academic Writing (SESAW). The SESAW was designed specifically for this study and was derived from the style of Schwarzer and Jerusalem's (1995) General Self-Efficacy Scale (GSES). Bandura (1997) has been clear that global self-efficacy measurements, such as the GSES, cannot adequately capture self-efficacy associated with a specific disposition or trait. Existing scales measuring WSE are diverse with some focusing on grammar and structural aspects of writing (e.g., Pajares, 2007) or ability to complete specific writing tasks (e.g., Prat-Sala \& Redford, 2012), while others have created more lengthy scales that divide WSE into multiple domains which include both tasks and skills as well as the macro perspective of assessing writing approach (e.g., Jones, 2008; MacArthur et al., 2016). Pajares (2003) states that a WSE scale will best capture the concept if it matches the outcomes expected in the investigation. The existing scales available in the literature during the planning phase of this study (fall 2011) did not adequately capture the writing challenges observed within the cohort of students in the nursing program. Therefore, the scale was developed with the course content and learning outcomes in mind. Problematic paper writing tasks such as the ability to search and interpret quality research sources, persevere in the face of writing difficulties, remain emotionally calm during the writing process, and write clearly about a chosen topic, became focus areas for assessment (see Table 1 for questionnaire items). The present scale was developed from the perspective that writing self-efficacy is both a skill and an emotions driven process. The SESAW is a 10-item 4-point Likert scale with response options ranging from strongly agree to strongly disagree. The possible range of scale scores is 10-40. Cronbach's alphas for the SESAW assessed during this study were established at .85-.90. Validity was assessed through comparisons with the GSES and was .50 and .53 at pretest and post-test respectively. 
Table 1

Items included in the Self-Efficacy Scale for Academic Writing

\begin{tabular}{l|l}
\hline 1 & I feel I have the skills to write a scholarly paper. \\
\hline 2 & Researching a topic comes easily to me. \\
\hline 3 & $\begin{array}{l}\text { If I encounter a problem with my chosen topic, I can find strategies to overcome my } \\
\text { difficulties. }\end{array}$ \\
\hline 4 & I am confident that I can write clearly so that others will understand my meaning. \\
\hline 5 & I am confident in my ability to understand the topic I've chosen. \\
\hline 6 & I have the skills to choose appropriate research materials to support my ideas on my topic. \\
\hline 7 & I am confident that I will understand the content of the research articles I find on my topic. \\
\hline 8 & With persistence, I can write about anything asked of me. \\
\hline 9 & Even when writing feels hard, I know I can complete the task on time. \\
\hline 10 & I will remain calm and in control through the writing process. \\
\hline
\end{tabular}

Visual Analog Scale-Anxiety (VAS-A). A visual analog scale was chosen for the measurement of anxiety for ease of use. A 100-mm line was created with the descriptors "not at all anxious" and "as anxious as I can imagine" on either end of the line. Respondents were asked to rate themselves based on how they felt about writing their next scholarly paper. Reliability and validity of visual analog scales for anxiety are discussed in Williams, Morlock, and Feltner (2010) which describes the VAS as correlating well with other anxiety scales (.60-.74) and achieving test-retest scores of .50-.61.

General Self-Efficacy Survey (GSES). Developed for the English language by Schwarzer and Jerusalem (1995), the GSES is a 10-item 4-point Likert-type questionnaire measuring general self-efficacy with a focus on coping and ability to handle hassles associated with daily life. GSE is a trait examining global personal self-efficacy assessing a person's efficacy to perform any task demanded of him/her. Respondents grade themselves on the items from "not at all true" to "exactly true." The total score is achieved by summing all responses. Scale scores range from 10-40. The inclusion of the GSES in this study was solely for the purpose of preliminary validity testing of the SESAW described above. Cronbach's alphas for the GSES have been found in the .76-.90 range. For the current study, Cronbach's alpha was .86. Criterion-related validity has been established through various positive correlations with dispositional optimism and work satisfaction, and negative correlations with anxiety, stress, and burnout (Schwarzer \& Jerusalem, 1995).

\section{Results}

Data were analyzed using the Statistical Program for the Social Sciences. Demographic characteristics of the sample are presented in Table 2. 
Table 2

Characteristics of Study Sample at T1 $(N=135)$

\begin{tabular}{|c|c|}
\hline & $\mathrm{N}(\%)^{*}$ \\
\hline \multicolumn{2}{|l|}{ Age } \\
\hline $18-24$ & $65(48.1 \%)$ \\
\hline $25-29$ & $30(22.2 \%)$ \\
\hline $30-34$ & $18(13.3 \%)$ \\
\hline $35-39$ & $10(7.4 \%)$ \\
\hline $40-44$ & $7(5.2 \%)$ \\
\hline $45+$ & $4(2.9 \%)$ \\
\hline \multicolumn{2}{|l|}{ Gender } \\
\hline Female & $117(86.7 \%)$ \\
\hline Male & $18(13.3 \%)$ \\
\hline \multicolumn{2}{|l|}{ English as an Additional Language } \\
\hline Yes & $28(20.7 \%)$ \\
\hline No & $107(79.3 \%)$ \\
\hline \multicolumn{2}{|l|}{ Previous Education } \\
\hline High School Diploma or Equivalent & $20(14.8 \%)$ \\
\hline Previous College diploma & $31(23.0 \%)$ \\
\hline $\begin{array}{r}\text { Previous College/University } \\
\text { Undergraduate degree }\end{array}$ & $12(8.9 \%)$ \\
\hline $\begin{array}{r}\text { Completed some College or university } \\
\text { level courses }\end{array}$ & $71(52.6 \%)$ \\
\hline Graduate degree & $1(0.7 \%)$ \\
\hline
\end{tabular}

\section{Self-Efficacy from the Beginning to Post Course}

The main hypothesis for this study expected that SESAW scores would improve from early in the course to post course, but that GSES would remain stable. This hypothesis was partially supported by dependent t-test. Average SESAW was moderate at both T1 $(M=29.72$, $S D=4.68)$ and $\mathrm{T} 2(M=30.67, S D=4.46)$ and neared a statistically significant improvement, $t(63)=-1.99, p=.051$. GSES, as expected, did not change significantly from early in the course $(M=31.19, S D=3.43)$ to post course $(M=31.50, S D=3.30), t(63)=-0.818, p=.416$.

\section{Anxiety from the Beginning to Post Course}

Anxiety was expected to be significantly reduced from early in the course to post course. This hypothesis was supported by dependent t-test. Anxiety levels were moderate and demonstrated a statistically significant reduction from the early course period $(M=55.19, S D=$ $25.40)$ to the post-course period $(M=45.53, S D=27.40), t(63)=2.91, p=.005$.

\section{Correlational Analysis}

As observed in past studies, the relationship between the SESAW and the VAS-A was expected to be negative and statistically significant. This hypothesis was supported. Anxiety 
correlated negatively with SESAW at both T1 and T2. Anxiety was also negatively correlated with the GSES. A summary of the Pearson's $r$ correlational findings is presented in Table 3.

Table 3

Correlation of VAS-A, SESAW, and GSES at T1 and T2 $(n=64)$

\begin{tabular}{l|l|l|l|l|l}
\hline & GSES T1 & VAS-A T1 & SESAW T1 & GSES T2 & VAS- A T2 \\
\hline $\begin{array}{l}\text { GSES } \\
\text { T1 }\end{array}$ & -- & & & & \\
\hline $\begin{array}{l}\text { VAS-A } \\
\text { T1 }\end{array}$ & $-0.242^{*}$ & -- & & & \\
\hline $\begin{array}{l}\text { SESAW } \\
\text { T1 }\end{array}$ & $0.504 * *$ & $-0.535^{* *}$ & -- & & \\
\hline $\begin{array}{l}\text { GSES } \\
\text { T2 }\end{array}$ & $0.589 * *$ & $-0.327 *$ & $0.404 * *$ & -- & \\
\hline $\begin{array}{l}\text { VAS-A } \\
\text { T2 }\end{array}$ & -0.176 & $0.493 * *$ & $-0.542 * *$ & $-0.327 *$ & -- \\
\hline $\begin{array}{l}\text { SESAW } \\
\text { T2 }\end{array}$ & $0.341^{*}$ & $-0.551 * *$ & $0.648 * *$ & $0.531 * *$ & $-0.644 *$ \\
\hline
\end{tabular}

$* \mathrm{p}<.01 * * \mathrm{p}<.001$

\section{Paper Task Completion and Writing Self-Efficacy}

It was expected that students who stayed on pace with course material and submitted their paper preparation notes, outline, and rough draft on the soft due dates for feedback would demonstrate higher self-efficacy when compared to students who did not submit these writing components on pace with the course. This hypothesis was not supported. Independent t-test identified that at T1, students who stayed with or nearly stayed with the prescribed paper task schedule or finished early $(M=29.21, S D=4.61)$ had significantly lower SESAW than students who self-identified as completing their paper late or last minute $(M=33.25 ; S D=3.73), t(62)=$ $-2.36, p=.021$. It is also significant to note that the number of students who reported submitting their assignments late or last minute was small $(\mathrm{n}=8,12.5 \%)$ compared to the on-pace or nearly on-pace group $(n=56,87.5 \%)$. A hand search of the questionnaires reporting late or last minute behaviour also identified that seven students self-reported a paper grade as A or A+ while one student reported receiving a $\mathrm{C}+$ grade.

\section{WSE as a Predictor of Self-Reported Paper Grade}

It was expected that SESAW scores at T1 would be a predictor of student self-reported paper grade. This hypothesis was supported. A regression analysis was performed to examine if SESAW at T1 acted as a predictor of self-reported grade on the final paper. In this sample, SESAW at T1 predicted $15.4 \%$ of the variance of final self-reported grade on the scholarly paper $(p<.001)$. 


\section{Previous Writing Experience and Help-Seeking Behaviour}

Differences were expected between these subgroups of students; however, none emerged. An independent t-test was performed on the SESAW scores at T1 in students with writing experience $(<5$ years since last academic paper, took previous writing courses, and writes regularly, $\mathrm{n}=51,64.6 \%$ ) and those without (never written a paper, $>5$ years since last academic paper, $\mathrm{n}=28,35.4 \%$ ) and it was non-significant. Non-significant results were found in T1 SESAW scores among students who did $(n=44,68.8 \%)$ or did not $(n=20,31.2 \%)$ request paper editing assistance from family and friends. Similarly, WSE scores between the students who met with an instructor $(\mathrm{n}=42,65.6 \%)$ and those that did not meet with an instructor $(\mathrm{n}=$ $22,34.4 \%)$ were not significant.

\section{Discussion}

The observed increase in writing self-efficacy, reduction in anxiety, and the ability of baseline SESAW scores to predict final paper grades are promising findings given the context of teaching writing instruction to an unfavourably large class size (173 students in two courses). Anxiety was significantly reduced in this population in the face of a $60 \%$ value on a scholarly paper assignment, but the post-test measure of anxiety may have captured their relief from hurdling this task rather than represent true decreased anxiety in anticipation of their next writing assignment. The VAS-A asked students to rate their anxiety based on their next scholarly paper. At T1, the expectations of the next scholarly paper were clear, and a $60 \%$ value to a final assignment could have negatively affected anxiety. At T2, with no assigned paper in the third term, the next scholarly paper was a hypothetical part of an unknown future. It was impossible to know what students were visualizing when asked to rate their anxiety based on an assignment they had not yet received information about.

In this study, WSE at T1 did not differ between the students who sought help and those who did not, which means that low self-efficacy students were also likely to seek help. This finding appears to contradict past assumptions with respect to WSE and help seeking (Jones, 2008; Walker, 2003; Woodrow, 2011), but most students in this sample may have sought help because it was strongly encouraged by the course instructor. Similar to our finding, Williams and Takaku (2011) assessed help seeking that was defined as writing centre visits and found it was the low self-efficacy students that made the most visits.

The most surprising finding was that students who reported completing their final papers late or last minute $(\mathrm{n}=8)$ had higher writing self-efficacy $(p=.021)$ than students who stayed on task with course materials and the timelines set out by the instructor $(n=56)$. Jones $(2008)$ has stated that beginning to write days in advance of a due date is a behaviour associated with high self-efficacy, and these results appear to contradict this assumption. Students with high selfefficacy are less likely to doubt they can complete the task successfully even with limited time. High self-efficacy students likely also spend more time thinking and planning their active writing phase but may not consider these planning activities a component of starting their paper. Emphasizing that researching, reading source articles, taking notes, creating outlines, and simply lying in bed and ruminating on their topic may help students connect how these activities are critical aspects of successful writing and are not necessarily facets of procrastination.

Self-efficacy is informed by previous experiences, previous mastery, and receiving feedback about competence during a past grading experience (Bandura, 1997). Similar to the finding in Sprenger (2013), the results of this study found no difference in WSE levels in 
students with past writing experience and those without. Past writing experience does not guarantee that those experiences were positive (Bandura, 1997; Sprenger, 2013; Woodrow, 2011). Writing traumas associated with negative past experiences originate from a past teacher's insensitivity, negative reactions and grades despite hard work, or humiliation from negative sharing experiences (Long, 2013). The first author has heard similar writing horrors from students both in conversation and as a part of the writing histories students submitted as their first writing exercise, which composed the qualitative data for this project. These negative experiences influence the mastery component of WSE. Most students' with past writing experience developed that experience in a discipline other than nursing. Differences in expectations, demands for correct use of APA formatting, and the demands of an unfamiliar nursing academic discourse may have influenced writing self-efficacy levels in students reporting experience.

\section{Study Limitations}

The results of this study are limited because the absence of a control group places in doubt that changes observed over time were due solely to participation in the scholarly writing course. While a true control group with random assignment may not be ethically possible in an educational environment, a time-control period where no writing takes place may at least provide some evidence about a possible maturation effect that can occur while learning to become a student in a new program.

Other threats to internal validity must also be identified. The convenience sample and the large attrition rate from pretest to post-test limits generalizability and sample representativeness. The timing of delivery of questionnaires created several limits to the interpretation of this data. The initial survey was distributed three to four classes after the start of the course and meant the students were well versed on the demands of the course and the final paper assignment. This knowledge may have had an influence on the degree of anxiety or writing self-efficacy reported in this analysis. The post-test was given early in the term that followed the course and contributed to a loss of follow-up of the students with the lowest grades. Because social persuasion, such as instructor feedback, is one of Bandura's stated sources of self-efficacy information, knowledge of final grades and the feedback received from the grading process may have influenced their reported writing self-efficacy.

Finally, preliminary testing of the SESAW that took place during this study has been promising, but further testing and refinement in different nursing populations will be necessary to establish the validity of the instrument. Validity testing and classic item analysis have been ongoing since the completion of this study, and results from this cohort and a subsequent cohort continue to demonstrate its effectiveness as a measure (please contact the first author for further information on the testing of this questionnaire).

\section{Implications for the Teaching of Academic Writing in Nursing}

The discipline-specific approach and scaffolding method explored in this research discuss the experience of introducing the scholarly expectations of writing within one baccalaureate nursing program. The nursing education literature purports discipline-specific writing courses as the superior method of writing instruction for nursing programs (Andre \& Graves, 2013; Gimenez, 2012; Luthy et al., 2009; Oermann et al., 2014), but there continues to be limited research to support this claim. The ability to discuss nursing's evidenced-based knowledge fluently is justification that learning to write proficiently may be able to influence clinical 
competence. Proficiency in nursing discourse as an outcome of skillful writing may be a more important outcome of discipline-specific writing instruction than students learning to chart clearly, although the latter is also important.

The writing course described in this study attempted to personalize the writing process for students by requesting reflective assignments, which required that they discuss their experience with writing. Depersonalization of writing is one contributing factor to students failing to recognize their own authorship and contributes to decreased self-efficacy related to writing ability (Pittam et al., 2009). Despite efforts to help students find a personal connection to their topic, writing conventions that discourage use of first person, require the application of rigid writing and style guide formatting rules, and demand corroboration of all ideas presented can also contribute to a sense of depersonalization with writing. These conventions, while not unique to nursing, have been reported as a common trait present in nursing's academic discourse (Gimenez, 2012; Whitehead, 2002; Pittam et al., 2009).

Reflective writing requested as part of this study data (analysis not discussed in this article) confirm many of the findings identified in the quantitative results: high anxiety causes doubt about capacity to write well, reports of both positive and negative past grading experiences have a corresponding influence on writing confidence, participants identified that they felt their writing confidence affected their grades, and there were several reports from students that they had written papers in past courses within hours of the due date and still achieved high grades. Reflection can help students connect with their personal authorial identity and assist students in comparing and contrasting their writing experiences from the past and present (Fernsten \& Reda, 2011). Future research should explore the influence of reflective assignments on WSE.

Conversations about writing must continue as students advance into the higher levels of their program as writing instruction does not end with an introductory course (Luthy et al., 2009; Oermann et al., 2014). Because self-efficacy has been identified as a trait that is not fixed, it is reasonable to expect that teaching methods and instructor involvement in student progress through scaffolding methods can change self-efficacy beliefs (Woodrow, 2011). While introductory writing courses, such as the course presented, require instruction of basic writing skills and tasks (Walsh et al., 2014), scaffolding models can be applied to any course at any level of a nursing program where increasingly complex nursing knowledge needs to be integrated into a written assignment demonstrating critical analysis or argument on a topic. The course described in this research was developed from a nursing perspective by an instructor with a background in English literature and creative writing. Instructor involvement was intense, and the feedback provided in the course was extensive. All course activities built toward their final academic paper.

The scaffolding instructional method described in the Appendix focused on recruiting students to value writing in a nursing program. Choice of paper topic to ensure engagement with the literature and then further encouraging choice by allowing the students to address their topic using the discussion points that most resonated with them were additional methods used to recruit students to the task of writing. In a short three-page paper, it was impossible for the students to complete a thorough discussion of every aspect of their topic, so collaborating with the students to help them identify topic-limiting strategies was required for success on this assignment. 
In their systematic review of the literature, Oermann et al. (2014) analyzed a wide variety of studies and discussion articles with no comparable interventions. Writing assignments, workshops, courses (both online and face to face), faculty feedback, peer review, rubric standardizations, and self-directed activities all have the potential to improve writing selfefficacy and performance, but structured research on the topic, especially in baccalaureate nursing populations, is currently inadequate. This study did not explore whether writing performance improved from the beginning of the course to the end, but testing the influence of scaffolding methods on writing quality could be valuable. Future research on writing should focus on following a cohort of students and examine their writing growth throughout an academic curriculum (Jones, 2008; Luthy et al., 2009; Oermann et al., 2014). If, as several authors claim, discipline-specific writing courses are preferable and show enhanced writing outcomes when compared to generic courses (Carstens, 2011; Luthy et al., 2009; Van de Poel \& Gasiorek, 2012), then it follows that discipline-specific investigations of writing are critical.

\section{Conclusion}

First-year nursing students can benefit from taking a discipline-specific writing course as both writing anxiety and writing self-efficacy can potentially be improved in this population; however, additional research is required to support this claim. Writing is both a technical, skillbased activity and an emotionally driven practice, and both components of this complex experience need to be examined. When teaching writing to nursing students, faculty need to be aware of the role that writing activities play in students learning the language of their profession and help students to connect with their own authorship through reflective practices. 


\section{References}

Andre, J. D., \& Graves, R. (2013). Writing requirements across nursing programs in Canada. Journal of Nursing Education, 52(2), 91-97. doi:10.3928/01484834-20130114-02

Antoniou, M., \& Moriarty, J. (2008). What can academic writers learn from creative writers? Developing guidance and support for lecturers in higher education. Teaching in Higher Education, 13(2), 157-167. doi:10.1080/13562510801923229

Bandura, A. (1997). Self-efficacy: The exercise of control. New York, NY: W. H. Freeman.

Benko, S. L. (2012). Scaffolding: An ongoing process to support adolescent writing development. Journal of Adolescent \& Adult Literacy, 56(4), 291-300. doi:10.1002/JAAL.00142

Carstens, A. (2011). Generic versus discipline-specific writing interventions: Report on a quasiexperiment. Southern African Linguistics and Applied Language Studies, 29(2), 149-165. doi:10.2989/16073614.2011.633363

Ekholm, E., Zumbrunn, S., \& Conklin, S. (2015). The relation of college student self-efficacy toward writing and writing self-regulation aptitude: Writing feedback perceptions as a mediating variable. Teaching in Higher Education, 20(2), 197-207. doi:10.1080/13562517.2014.974026

Fernsten, L. A., \& Reda, M. (2011). Helping students meet the challenges of academic writing. Teaching in Higher Education, 16(2), 171-182. doi:10.1080/13562517.2010.507306

Gazza, E. A., \& Hunker, D. F. (2012). Facilitating scholarly writer development: The writing scaffold. Nursing Forum, 47(4), 278-285. doi:10.1111/j.1744-6198.2012.00275.x

Gimenez, J. (2012). Disciplinary epistemologies, generic attributes and undergraduate academic writing in nursing and midwifery. Higher Education, 63, 401-419. doi:10.1007/s10734011-9447-6

Goodman, S. B., \& Cirka, C. C. (2009). Efficacy and anxiety: An examination of writing attitudes in a first-year seminar. Journal on Excellence in College Teaching, 20(3), 5-28.

Harris, R. (2015). Evaluating internet research sources. Retrieved from http://www.virtualsalt.com/evalu8it.htm

Jones, E. (2008). Predicting performance in first-semester college basic writers: Revisiting the role of self-beliefs. Contemporary Educational Psychology, 33, 209-238. doi:10.1016/j.cedpsych.2006.11.001

Luthy, K. E., Peterson, N. E., Lassetter, J. H., \& Callister, L. C. (2009). Successfully incorporating writing across the curriculum with advanced writing in nursing. Journal of Nursing Education, 48(1), 54-59. doi:10.3928/01484834-20090101-07

Long, T. L. (2013). Self-efficacy and writing beliefs in nursing. Nurse Author \& Editor, 23(4), $1-4$.

MacArthur, C. A., Philippakos, Z. A., \& Graham, S. (2016). A multicomponent measure of writing motivation with basic college writers. Learning Disability Quarterly, 39(1), 3143. doi: $10.1177 / 0731948715583115$ 
McVey, D. (2008). Why all writing is creative writing. Innovations in Education and Teaching International, 45(3), 289-294. doi:10.1080/14703290802176204

Miller, L. C., Russell, C. L., Cheng, A. L., \& Skarbek, A. J. (2015). Evaluating undergraduate nursing students' self-efficacy and competence in writing: Effects of a writing intensive intervention. Nurse Education in Practice, 15(3), 174-180. doi:10.1016/j.nepr.2014.12.002

Mandleco, B. L., Bohn, C., Callister, L. C., Lassetter, J., \& Carlton, T. (2012). Integrating advanced writing content into a scholarly inquiry in nursing course. International Journal of Nursing Education Scholarship, 9(1), 1-16. doi:10.1515/1548-923X.2213

Martinez, C. T., Kock, N., \& Cass, J. (2011). Pain and pleasure in short essay writing: Factors predicting university students' writing anxiety and writing self-efficacy. Journal of Adolescent \& Adult Literacy, 54(5), 351-360. doi:10.1598/JAAL.54.5.5

Oermann, M. H., Leonardelli, A. K., Turner, K. M., Hawks, S. J., Derouin, A. L., \& Hueckel, R. M. (2014). Systematic review of educational programs and strategies for developing students' and nurses' writing skills. Journal of Nursing Education, 54(1), 28-34. doi:10.3928/01484834-20141224-01

Pajares, F. (2003). Self-efficacy beliefs, motivation, and achievement in writing: A review of the literature. Reading \& Writing Quarterly, 19, 139-158. doi:10.1080/10573560390143085

Pajares, F. (2007). Empirical properties of a scale to assess writing self-efficacy in school contexts. Measurement and Evaluation in Counselling and Development, 39, 239-249.

Pajares, F., \& Johnson, M. J. (1994). Confidence and competence in writing: The role of selfefficacy, outcome expectancy, and apprehension. Research in the Teaching of English, 28(3), 313-331.

Pittam, G., Elander, J., Lusher, J., Fox, P., \& Payne, N. (2009). Student beliefs and attitudes about authorial identity in academic writing. Studies in Higher Education, 34(2), 153170. doi:10.1080/03075070802528270

Prat-Sala, M., \& Redford, P. (2012). Writing essays: Does self-efficacy matter? The relationship between self-efficacy in reading and in writing and undergraduate students' performance in essay writing. Educational Psychology, 32(1), 9-20. doi:10.1080/01443410.2011.621411

Sanders-Reio, J., Alexander, P. A., Reio, T. G., \& Newman, I. (2014). Do students' beliefs about writing relate to their writing self-efficacy, apprehension, and performance? Learning and Instruction, 33, 1-11. doi:10.1016/j.learninstruc.2014.02.001

Schwarzer, R., \& Jerusalem, M. (1995). General self-efficacy scale. In J. Weinman, S. Wright, \& M. Johnston (Eds.). Measures in Health Psychology - A user's portfolio: Causal and control beliefs (pp. 35-37). Windsor, UK: NFER-Nelson.

Sprenger, L. (2013). Perceptions and writing experiences of nursing students: A mixed methods exploration of writing self-efficacy (Doctoral dissertation) Capella University. Retrieved from http://gradworks.umi.com/36/05/3605270.html

Troxler, H., Vann, J. C. J., \& Oermann, M. H. (2011). How baccalaureate nursing programs teach writing. Nursing Forum, 46(4), 280-288. doi:10.1111/j.1744-6198.2011.00242.x 
Van de Poel, K., \& Gasiorek, J. (2012). Effects of an efficacy-focused approach to academic writing on students' perceptions of themselves as writers. Journal of English for Academic Purposes, 11, 294-303. doi:10.1016/j.jeap.2012.07.003

Vanderburg, R. M. (2006). Reviewing research on teaching writing based on Vygotsky's Theories: What can we learn? Reading \& Writing Quarterly, 22, 375-393. doi:10.1080/10573560500455778

Walker, B. J. (2003). The cultivation of student self-efficacy in reading and writing. Reading \& Writing Quarterly, 19, 173-187. doi:10.1080/10573560308217

Walsh, K. P., Prokos, A., \& Bird, S. R. (2014). Building a better term paper: Integrating scaffolded writing and peer review. Teaching Philosophy, 37(4), 481-497. doi:10.5840/teachphil201410225

Whitehead, D. (2002). The academic writing experiences of a group of student nurses: A phenomenological study. Journal of Advanced Nursing, 38(5), 498-506. doi:10.1046/j.1365-2648.2002.02211.x

Williams, V. S. L., Morlock, R. J., \& Feltner, D. (2010). Psychometric evaluation of a visual analog scale for the assessment of anxiety. Heath and Quality of Life Outcomes, 8(57), 18. doi:10.1186/1477-7525-8-57

Williams, J. D., \& Takaku, S. (2011). Help seeking, self-efficacy, and writing performance among college students. Journal of Writing Research, 3(1), 1-18. doi:10.17239/jowr2011.03.01.1

Woodrow, L. (2011). College English writing affect: Self-efficacy and anxiety. System, 39(4), 510-522. doi:10.1016/j.system.2011.10.017

Woody, J. D., Zeleny, M. G., D’Souza, H. J., Harder, J., Reiser, J., \& Szto, P. (2014). Student progress in a social work writing course: Self-efficacy, course objectives, and skills. Journal of Social Work Education, 50, 507-524. doi:10.1080/10437797.2014.917895

Zimmerman, B. J., \& Bandura, A. (1994). Impact of self-regulatory influences on writing course attainment. American Educational Research Journal, 31(4), 845-862. doi:10.3102/00028312031004845 


\section{Appendix}

Applying Bandura's Self-Efficacy Theory and Scaffolding Instructional Methods to the Scholarly Writing Course*

\begin{tabular}{|c|c|c|c|c|c|c|}
\hline 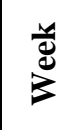 & $\begin{array}{c}\text { Course } \\
\text { Module }\end{array}$ & $\begin{array}{c}\text { Related Assignment and } \\
\text { Scholarly Paper Task }\end{array}$ & Instructor Responsibility & $\begin{array}{l}\text { Scaffolding as a } \\
\text { Process Model } \\
\text { (Benko, 2012) }\end{array}$ & $\begin{array}{c}\text { Sources of Self- } \\
\text { Efficacy (Bandura, } \\
\text { 1997) }\end{array}$ & $\begin{array}{c}\text { Rationale for } \\
\text { Writing Activity }\end{array}$ \\
\hline 1 & Writing Voice & $\begin{array}{l}\text { Writing Exercise \#1 }(3 \%)-\mathrm{A} \\
\text { reflection on my history as a } \\
\text { writer. } \\
\text { Scholarly paper task: Scholarly } \\
\text { paper topic choices presented. } \\
\text { Students also reflect on what } \\
\text { topic about which they may like } \\
\text { to write. }\end{array}$ & $\begin{array}{l}\text { Prepare course materials } \\
\text { and answers emails and } \\
\text { questions (applies to all } \\
\text { modules). } \\
\text { Explain scholarly paper } \\
\text { topics and their } \\
\text { applicability to nursing. } \\
\text { Support students in their } \\
\text { paper topic choices. }\end{array}$ & $\begin{array}{l}\text { Task Selection: } \\
\text { Appropriateness of } \\
\text { task (first-year level of } \\
\text { complexity). } \\
\text { Student choice allows } \\
\text { for } \text { ownership of topic. } \\
\text { Recruit student to the } \\
\text { value of academic } \\
\text { writing in nursing. }\end{array}$ & $\begin{array}{l}\text { Mastery } \\
\text { (distinguishing } \\
\text { academic voice } \\
\text { from other writing } \\
\text { voices) } \\
\text { Social persuasion } \\
\text { (feedback from } \\
\text { instructor) }\end{array}$ & $\begin{array}{l}\text { Acquaint students } \\
\text { with their identity as } \\
\text { "authors" }\end{array}$ \\
\hline 2 & Plagiarism & $\begin{array}{l}\text { Writing Exercise \#2 (3\%)- } \\
\text { Summarizing the content of a } \\
\text { short video that tells a story } \\
\text { Scholarly paper task: Continue } \\
\text { to reflect on topic options. Begin } \\
\text { preliminary web search for } \\
\text { applicable research materials. }\end{array}$ & $\begin{array}{l}\text { Interactive class discussion } \\
\text { about academic } \\
\text { misconduct. } \\
\text { Provide examples of } \\
\text { plagiarized writing. } \\
\text { Alleviate student anxiety } \\
\text { about academic } \\
\text { misconduct. }\end{array}$ & $\begin{array}{l}\text { Teacher instruction: } \\
\text { Mark critical features } \\
\text { (clarify confusing } \\
\text { aspects of the task, } \\
\text { which allows students } \\
\text { to progress forward } \\
\text { toward completion) } \\
\text { Teacher stance: } \\
\text { Frustration control } \\
\text { (anxiety reduction) }\end{array}$ & $\begin{array}{l}\text { Mastery } \\
\text { (understanding } \\
\text { academic } \\
\text { misconduct) } \\
\text { Emotional arousal } \\
\text { (anxiety control) } \\
\text { Social persuasion }\end{array}$ & $\begin{array}{l}\text { Prevent academic } \\
\text { misconduct }\end{array}$ \\
\hline 3 & $\begin{array}{l}\text { Paraphrasing, } \\
\text { Citation, } \\
\text { Direct } \\
\text { Quotation }\end{array}$ & $\begin{array}{l}\text { APA online Quiz \#1 (5\%) } \\
\text { Citation and Direct Quotation } \\
\text { Writing Exercises \#3, 4, } 5 \text { (9\%) } \\
\text { (completed in different weeks of } \\
\text { the course) } \\
\text { Build capacity to summarize, } \\
\text { paraphrase and synthesize 1, } 2 \text {, } \\
\text { then } 3 \text { provided short excerpts } \\
\text { into a paragraph on a health-, } \\
\text { nursing-, social-, or psychology- } \\
\text { related topics. }\end{array}$ & $\begin{array}{l}\text { Provide formative } \\
\text { feedback on writing } \\
\text { exercises (applies to } \\
\text { exercises } 1 \text { and } 2 \text { as well). } \\
\text { These exercises received } \\
\text { full marks for satisfactory } \\
\text { completion regardless of } \\
\text { the number of errors made. } \\
\text { Give feedback on } \\
\text { grammar, APA citation, } \\
\text { and clarity of writing. }\end{array}$ & $\begin{array}{l}\text { Teacher instruction: } \\
\text { Reduce the degrees of } \\
\text { freedom of the task } \\
\text { (simplifying the } \\
\text { demands of the task } \\
\text { and breaking it down } \\
\text { into its components) }\end{array}$ & $\begin{array}{l}\text { Mastery (learning to } \\
\text { paraphrase and cite) } \\
\text { Emotional arousal } \\
\text { (anxiety control) } \\
\text { Social persuasion }\end{array}$ & $\begin{array}{l}\text { Developing habits of } \\
\text { citing sources during } \\
\text { the act of } \\
\text { paraphrasing. } \\
\text { Exposing students to } \\
\text { the creativity } \\
\text { required to combine } \\
\text { sources into a new } \\
\text { whole, with } \\
\text { increasing } \\
\text { complexity as the }\end{array}$ \\
\hline
\end{tabular}




\begin{tabular}{|c|c|c|c|c|c|c|}
\hline & & $\begin{array}{l}\text { Correct APA citation of } \\
\text { paraphrases and direct quotes } \\
\text { used as required. } \\
\text { Scholarly paper task: Solidify } \\
\text { topic choice }\end{array}$ & $\begin{array}{l}\text { Comment when student } \\
\text { tends to paraphrase/ } \\
\text { summarize provided } \\
\text { sources one at a time in the } \\
\text { order presented rather than } \\
\text { giving a fluent synthesis } \\
\text { that creates a new whole. }\end{array}$ & & & $\begin{array}{l}\text { number of sources } \\
\text { increases with each } \\
\text { exercise. }\end{array}$ \\
\hline 4 & $\begin{array}{c}\text { Peer Reviewed } \\
\text { Journals }\end{array}$ & $\begin{array}{l}\text { Scholarly paper task: Search } \\
\text { peer-reviewed databases for peer- } \\
\text { reviewed journals on chosen } \\
\text { topic. Decide on the fit of located } \\
\text { articles for topic focus. }\end{array}$ & $\begin{array}{l}\text { Library orientation. } \\
\text { On request, the review } \\
\text { peer-review status of } \\
\text { articles located. } \\
\text { Alleviate writing anxiety } \\
\text { (applies to all modules) }\end{array}$ & $\begin{array}{l}\text { Teacher instruction: } \\
\text { Reduce the degrees of } \\
\text { freedom of the task } \\
\text { Mark critical features } \\
\text { Direction maintenance } \\
\text { (ensuring students stay } \\
\text { on task with the } \\
\text { appropriate focus) } \\
\text { Teacher stance: } \\
\text { Frustration control }\end{array}$ & $\begin{array}{l}\text { Mastery } \\
\text { (recognizing and } \\
\text { searching for peer- } \\
\text { reviewed sources) } \\
\text { Emotional arousal } \\
\text { (anxiety control) } \\
\text { Social persuasion }\end{array}$ & $\begin{array}{l}\text { Emphasizing that } \\
\text { peer-reviewed } \\
\text { sources are the } \\
\text { highest in the } \\
\text { hierarchy of literature } \\
\text { used for academic } \\
\text { purposes. } \\
\text { Provide basic } \\
\text { literature search } \\
\text { skills beyond Google. }\end{array}$ \\
\hline 5 & $\begin{array}{c}\text { Website } \\
\text { Evaluation }\end{array}$ & $\begin{array}{l}\text { Website Evaluation Assignment } \\
(10 \%) \text { : Choose one web-based } \\
\text { article (not from an academic } \\
\text { peer-reviewed source, news } \\
\text { source, or a homepage of a } \\
\text { website) and complete a provided } \\
\text { template to assess that article } \\
\text { using the CARS checklist } \\
\text { (Harris, 2015). } \\
\text { Scholarly paper task: Ensure } \\
\text { minimum expected sources for } \\
\text { the scholarly paper assignment } \\
\text { have been located: } 3 \text { peer- } \\
\text { reviewed journals, } 1 \text { web source, } \\
\text { and } 1 \text { book specific to the topic } \\
\text { (a second web source may be } \\
\text { appropriate in the case of some } \\
\text { topics). } \\
\text { Read and highlight all research } \\
\text { material. }\end{array}$ & $\begin{array}{l}\text { Assess website evaluations } \\
\text { for student ability to } \\
\text { identify factors that } \\
\text { increase or decrease the } \\
\text { credibility, accuracy, } \\
\text { reasonableness or support } \\
\text { (CARS) of the chosen } \\
\text { website. }\end{array}$ & $\begin{array}{l}\text { Teacher instruction: } \\
\text { Reduce the degrees of } \\
\text { freedom of the task } \\
\text { Mark critical features } \\
\text { Direction maintenance } \\
\text { Teacher stance: } \\
\text { Frustration control }\end{array}$ & $\begin{array}{l}\text { Mastery } \\
\text { (recognizing that not } \\
\text { all web sources are } \\
\text { trustworthy) } \\
\text { Emotional arousal } \\
\text { (anxiety control) } \\
\text { Social persuasion }\end{array}$ & $\begin{array}{l}\text { Beginning to develop } \\
\text { the career-long skill } \\
\text { of critically } \\
\text { analyzing the } \\
\text { trustworthiness of } \\
\text { web-based } \\
\text { information }\end{array}$ \\
\hline
\end{tabular}




\begin{tabular}{|c|c|c|c|c|c|c|}
\hline 6 & $\begin{array}{l}\text { Notes and } \\
\text { Outlines }\end{array}$ & $\begin{array}{l}\text { Scholarly paper task: Create } \\
\text { note pages summarizing the main } \\
\text { points of sources. Begin to work } \\
\text { on an outline of planned paper } \\
\text { topic choosing } 2-3 \text { main headings } \\
\text { to address that topic's focus. }\end{array}$ & $\begin{array}{l}\text { Review outlines on request } \\
\text { from students. Watch for } \\
\text { the tendency to try to cover } \\
\text { too much content in a } \\
\text { three-page paper, and for } \\
\text { planned writing topics that } \\
\text { are off the stated focus of } \\
\text { the paper. }\end{array}$ & $\begin{array}{l}\text { Teacher instruction: } \\
\text { Reduce the degrees of } \\
\text { freedom of the task } \\
\text { Mark critical features } \\
\text { Direction maintenance } \\
\text { Demonstrate (model } \\
\text { examples of } \\
\text { appropriate notes and } \\
\text { outlines) } \\
\text { Teacher stance: } \\
\text { Frustration control } \\
\text { Collaboration (guide } \\
\text { rather than dictate) }\end{array}$ & $\begin{array}{l}\text { Mastery (writing } \\
\text { process elements) } \\
\text { Emotional arousal } \\
\text { (anxiety control) } \\
\text { Social persuasion }\end{array}$ & $\begin{array}{l}\text { Developing capacity } \\
\text { to plan and organize } \\
\text { writing activities. }\end{array}$ \\
\hline 7 & $\begin{array}{c}\text { APA } \\
\text { Formatting }\end{array}$ & $\begin{array}{l}\text { APA online quiz } \# 2(5 \%)- \\
\text { Grammar and APA formatting } \\
\text { Scholarly paper task: Begin } \\
\text { drafting sections of paper. } \\
\text { Consider topic-limiting strategies } \\
\text { to provided depth of discussion } \\
\text { on key points rather than try to } \\
\text { address all aspects of the topic. }\end{array}$ & $\begin{array}{l}\text { Begin setting appointment } \\
\text { schedule to review full } \\
\text { drafts of papers and other } \\
\text { extensive one-on-one } \\
\text { consultations with } \\
\text { students. These } \\
\text { appointments are booked } \\
\text { on the initiative of the } \\
\text { student. }\end{array}$ & $\begin{array}{l}\text { Teacher instruction: } \\
\text { Reduce the degrees of } \\
\text { freedom of the task } \\
\text { Mark critical features } \\
\text { Direction maintenance } \\
\text { Demonstrate (model } \\
\text { examples of APA } \\
\text { formatting) } \\
\text { Teacher stance: } \\
\text { Frustration control } \\
\text { Collaboration }\end{array}$ & $\begin{array}{l}\text { Mastery (cosmetic } \\
\text { appearance of an } \\
\text { APA paper) } \\
\text { Emotional arousal } \\
\text { (anxiety control) } \\
\text { Social persuasion }\end{array}$ & $\begin{array}{l}\text { Teaching computer } \\
\text { skills to apply APA } \\
\text { format }\end{array}$ \\
\hline 8 & $\begin{array}{c}\text { APA } \\
\text { Reference } \\
\text { Lists }\end{array}$ & $\begin{array}{l}\text { APA online quiz \#3 (5\%) - APA } \\
\text { reference list format } \\
\text { Scholarly paper task: Continue } \\
\text { drafting paper. Create reference } \\
\text { list for the sources included in } \\
\text { the paper. }\end{array}$ & $\begin{array}{l}\text { Continue with paper draft } \\
\text { reviews and student } \\
\text { consultations. }\end{array}$ & $\begin{array}{l}\text { Teacher instruction: } \\
\text { Reduce the degrees of } \\
\text { freedom of the task } \\
\text { Mark critical features } \\
\text { Direction maintenance } \\
\text { Demonstrate (model } \\
\text { examples of APA } \\
\text { reference lists, and } \\
\text { completed papers) } \\
\text { Teacher stance: } \\
\text { Frustration control } \\
\text { Collaboration }\end{array}$ & $\begin{array}{l}\text { Mastery (reference } \\
\text { list appearance) } \\
\text { Emotional arousal } \\
\text { (anxiety control) } \\
\text { Social persuasion }\end{array}$ & $\begin{array}{l}\text { Order of reference } \\
\text { list and importance o } \\
\text { authorship on } \\
\text { academic papers. }\end{array}$ \\
\hline
\end{tabular}




\begin{tabular}{|c|c|c|c|c|c|c|}
\hline 9 & $\begin{array}{l}\text { Revising an } \\
\text { Academic } \\
\text { Paper }\end{array}$ & $\begin{array}{l}\text { Following the guidelines } \\
\text { provided, revise paper for } \\
\text { mechanical errors, content } \\
\text { clarity, and depth of discussion. } \\
\text { Scholarly paper task: Submit } \\
\text { by due date: notes, outline, one } \\
\text { copy of a rough draft, and } \\
\text { completed paper to the assigned } \\
\text { drop boxes on the online learning } \\
\text { platform. } \\
\text { Scholarly Paper Assignment due } \\
(60 \%)\end{array}$ & $\begin{array}{l}\text { Continue with student draft } \\
\text { reviews and paper } \\
\text { consultations. } \\
\text { Provide orientation to all } \\
\text { instructors assigned to } \\
\text { grade papers. } \\
\text { Encourage student-to- } \\
\text { student peer review. }\end{array}$ & $\begin{array}{l}\text { Teacher instruction: } \\
\text { Reduce the degrees of } \\
\text { freedom of the task } \\
\text { Mark critical features } \\
\text { Direction maintenance } \\
\text { Demonstrate } \\
\text { Teacher stance: } \\
\text { Frustration control } \\
\text { Collaboration } \\
\text { Letting go: } \\
\text { Internalization } \\
\text { (students complete } \\
\text { paper independently) }\end{array}$ & $\begin{array}{l}\text { Mastery (revision } \\
\text { phase of writing) } \\
\text { Emotional arousal } \\
\text { (anxiety control) } \\
\text { Social persuasion } \\
\text { Vicarious } \\
\text { experiences } \\
\text { (student-to-student } \\
\text { peer review) }\end{array}$ & $\begin{array}{l}\text { Instilling an } \\
\text { independent sense of } \\
\text { accomplishment in } \\
\text { students completing a } \\
\text { paper. } \\
\text { The submission of } \\
\text { notes, outlines, and } \\
\text { rough draft is both } \\
\text { for feedback } \\
\text { purposes and } \\
\text { plagiarism prevention } \\
\text { (an audit trail of the } \\
\text { student's writing } \\
\text { process) }\end{array}$ \\
\hline
\end{tabular}

* This Appendix details the course structure as it was during the period of the research study. In subsequent years, the course structure was modified to reduce the number of assignments and instructor workload. The three online quizzes were combined into two. The five writing exercises were reduced to three: the initial reflection and paraphrasing two and three sources. A final reflective assignment was added that asked students to reflect upon their writing process and apply the structural basics of APA, which require computer skills (margins, double spacing, header, etc.). 